\title{
BARRANCOS DE CUSCUZ DE MILHO E UM RIO DE LEITE: ALIMENTAÇÃO, IDENTIDADE E PATRIMÔNIO NO SERTÃO DE CANUDOS
}

CORN COUSCOUS RAVINES AND A RIVER OF MILK: FOOD, IDENTITY AND HERITAGE IN THE SERTÃO OF CANUDOS

\section{Kadma Marques Rodrigues}

kadmamarques@yahoo.com.br Doutora em Sociologia, docente permanente do Programa de Pós-Graduação em Sociologia (PPGS-UECE), coordenadora do Observatório Cearense da Cultura Alimentar (OCCA), Universidade Estadual do Ceará (UECE)

ORCID: https://orcid.org/0000-0002-7310-958X

\section{Pedro Victor Moura Lima}

pedrovictorlima@hotmail.com.br Doutorando no Programa de Pós-Graduação em Sociologia (PPGS) Universidade Estadual do Ceará (UECE) ORCID: https://orcid.org/0000-0001-6805-8100

\section{(2) $\odot \Theta(\odot)$}

Esta obra está licenciada sob uma licença Creative Commons Attribution-NonCommercial-ShareAlike 4.0 International License.

\section{RESUMO}

O presente artigo procura compreender como práticas alimentares que concorreram para a afirmação de marcos identitários no âmbito do movimento social liderado por Antônio Conselheiro, no último quartel do século XIX, repercutem atualmente naquele território. De forma fragmentária, as referências à alimentação encontram-se há muito no debate sobre Canudos, por vezes associadas a supostas manifestações do desiquilíbrio mental do Conselheiro e dos milhares de homens e mulheres que o seguiam. Contudo, a imagem negativa atribuída ao alegado "fanatismo" e alienação dos conselheiristas tem recuado frente àquela da coletividade que procurava inserir-se na realidade que a rodeava, a partir de uma perspectiva identitária particular, positivada pela dimensão religiosa. $\mathrm{O}$ atual processo de patrimonialização da herança conselheirista integra essa inversão simbólica, na qual tais particularidades resultam em submissão de aspectos da vida econômica a normas comunitárias de produção, distribuição e consumo, inclusive de víveres que compunham o repertório alimentar dos sertanejos.

Palavras-chave: Canudos; alimentação; identidade; patrimônio. 


\begin{abstract}
This article seeks to understand how eating practices that contributed to the affirmation of identity milestones within the social movement led by Antônio Conselheiro, in the last quarter of the 19th century, have repercussions in that territory. In a fragmentary way, the references to food have long been inside the debate on Canudos, sometimes associated with alleged manifestations of the mental imbalance of Conselheiro and of the thousands of men and women who followed him. However, the negative image attributed to this alleged "fanaticism" and alienation of his following has retreated in the face of a collective that sought to insert itself in the reality that surrounded it, from a particular identity perspective, affirmed by the religious dimension. The current process of patrimonialization of the conselheirista inheritance integrates this symbolic inversion, in which such particularities result in the submission of aspects of economic life to community norms of production, distribution and consumption, including food items that composed the feeding repertoire of the local inhabitants.
\end{abstract}

Keywords: Canudos; food; identity, heritage.

\title{
INTRODUÇÃO
}

Até os dias atuais, a comunidade de Canudos tem despertado discussões e debates, tal como também ocorrera à época da guerra que dizimou o arraial (1896-1897), quando, no Rio de Janeiro, então capital federal, as notícias acerca das batalhas que ocorriam no norte da Bahia pareciam contradizer a perspectiva de modernidade auspiciada pela recém-proclamada República. Canudos, um povoado pobre, liderado por um "fanático religioso", que não reconhecia a representatividade do novo regime político, resistiu a três expedições militares, munidas do que havia de armamento mais moderno no Exército brasileiro. Na quarta expedição, diante da qual a cidadela sucumbiu, o próprio Ministro da Guerra, o Marechal Carlos Bittencourt, partira para o solo baiano, organizando as operações militares.

Finda a guerra, em outubro de 1897, com um saldo de aproximadamente vinte mil mortos, Canudos tornou-se tema de debates não apenas em virtude do massacre que vitimara a sua população, mas também em razão das condições de vida na comunidade fundada em 1893, sob a liderança do religioso cearense Antônio Vicente Mendes Maciel (18301897), que entrou para a história como Antônio Conselheiro. Era tão espantoso o fato dos “jagunços” resistirem a sucessivas ações do Exército, quanto a comunidade estabelecida às margens do rio Vaza-barris abrigar o segundo maior contingente populacional da Bahia, mesmo sem contar com qualquer auxílio das autoridades civis ou religiosas. 
Dentre os que renegam a capacidade dos conselheiristas de estabelecer uma organização social original e dinâmica, havia os defensores da "modernidade" e do "progresso", que entendiam a comunidade como um exemplo de obstáculo para a entrada do Brasil no "concerto das Nações civilizadas". Euclides da Cunha, que conhecera os estertores da campanha contra Canudos, na condição de jornalista correspondente, propôs-se, no seu célebre livro Os sertões (1902), a realizar uma "defesa" da população sertaneja, para a qual, no entanto, não via alternativa que não fosse o seu desaparecimento, "esmagada" que seria pela "civilização”. Nesse sentido, não faltaram, no rebuscado vocabulário euclidiano, expressões que evidenciaram a suposta rusticidade das populações sertanejas, retratadas como retardatárias, rudes e, até mesmo, inúteis, chegando o autor, no citado livro, a referir-se aos "homens mais bravos e mais inúteis da nossa terra” (CUNHA, 2016 [1902], p. 225).

Nessa concepção do sertanejo como um bárbaro, a produção de víveres atenderia apenas à satisfação das carências básicas de uma população em permanente luta contra o meio. Desse modo, mesmo os elementos de provisão alimentar figuram como ranhuras no panorama geral de escassez que encerra o povo dos sertões, sendo a alimentação constantemente deformada pela predominante presença da fome. A compreensão dessa visão "civilizada", ante os meios de vida de seus "rudes compatriotas", abrange uma ideia de modernidade que, voltada para as dinâmicas macroeconômicas, "costuma atrelar subsistência a subdesenvolvimento", conforme assinala Bartelt (1999, p. 48).

Distante da noção de abundância e de racionalidade da produção em larga escala, com suas projeções de mercado, estatísticas e cálculos logísticos, a atividade de subsistência despertava nos defensores dessa modernidade os mesmos pudores de que falava Josué de Castro (2007, p. 12) acerca da relutância em se tratar do tema da necessidade alimentar, o qual soaria "um tanto chocante para uma cultura racionalista como a nossa, que procura por todos os meios impor o predomínio da razão sobre o dos instintos na conduta humana”.

O viés naturalista de Euclides da Cunha apresentava os dados do que seria essa subsistência, com ênfase na luta implacável contra o meio. Contudo, o autor de Os sertões submete as condições materiais do sertanejo aos rigores de um determinismo que tudo molda. Este sofreria a influência inescapável do meio e da raça, ao mesmo tempo em que apresentaria uma capacidade inata de refazer-se, tal qual a vegetação que o circunda, por estar adaptado a uma natureza hostil.

Ainda em Os sertões, a alimentação aparece por vezes torturada, ora pela própria fome, a qual imporia o consumo de alimentos "nocivos", que antes intoxicam do que nutrem; ora pelo "fanatismo", expressão de mentes doentias, as quais teriam nos rigores alimentares as manifestações de sua patologia. Em ambos os casos, o que sobressai é a fome, em suas consequências físicas e mentais. Não por acaso, Josué de Castro 
dedica a sua célebre Geografia da fome à memória de um Euclides da Cunha "sociólogo da fome".

Em Geografia da Fome, obra de 1946, pode ser verificado a fonte das reservas físicas dos sertanejos. O livro do médico e geógrafo Josué de Castro aponta os pormenores do regime alimentar nos sertões nordestinos e suas consequências para a população que vive nessa área do país. O autor salienta a influência dos hábitos alimentares, tanto em termos quantitativos quanto qualitativos, nas dinâmicas culturais e econômicas da sociedade, sem ceder ao que ele denomina de "biologismo", ou seja, um determinismo estabelecido por fatores biológicos ou naturais, como fez Euclides da Cunha.

Contudo, no que tange a Canudos, Josué de Castro replicou a base argumentativa de Euclides da Cunha, considerando a primazia de um fanatismo religioso de ordem patológica. Ainda que o autor de Geografia da Fome aponte as condições materiais desse "fanatismo", enquadrando-o entre os sintomas psicológicos e morais da fome, e alerte para a complexidade de causas que envolvem o fenômeno messiânico no Nordeste, sua compreensão do movimento religioso como "fuga à miséria" não reconhece o advento da comunidade sertaneja como uma alternativa positiva de sobrevivência à constante ameaça da miséria.

De fato, o arraial conselheirista representou uma alternativa de subsistência na mesma medida em que os quilombos do Nordeste açucareiro também o foram, na interpretação do próprio Josué de Castro, que louvava o papel quilombola na produção de alimentos em uma região vitimada pela pobreza alimentar gerada pela monocultura da cana. E tal como Gomes (2016) destacou acerca dos quilombos, apontando os elos econômicos desses povoados com a sociedade envolvente, a comunidade de Canudos também não se encontrava isolada do seu entorno. $\mathrm{Na}$ verdade, o arraial conselheirista produzia um perceptível impacto sobre a economia da região. Nesse sentido, Garcez (1977, p. 21) aponta o estabelecimento de uma "rede de relações comerciais perfeitamente definidas", a qual envolvia, além de Canudos, localidades como Juazeiro e Salvador.

Conforme aponta Bartelt (1999), são diversos os relatos que descrevem um ambiente de "fartura" no arraial de Canudos. Uma "abundância", que, como lembra o referido autor, é, por vezes, desconsiderada, embora configure "uma normalidade sertaneja" (Bartelt, 1999, p. 48). Para além da normalidade, em Canudos, as possibilidades de produção da vida material estavam associadas à intervenção de fatores religiosos, que favoreceriam Canudos, em virtude da observância dos preceitos da verdadeira fé católica, os quais estariam sendo negligenciados pela sociedade republicana. Acerca desse favorecimento, Reesink (1999) destaca:

Já que Deus comanda a subsistência dos homens no seu trabalho na terra, em especial na roça para produzir os legumes de sua comida diária, a bonança da boa produção implica em uma grandeza reveladora 
do reconhecimento e sanção divina da correção do modo de vida dos homens em Belo Monte (REESINK, 1999, p. 156).

O presente artigo visa compreender como os meios de subsistência desenvolvidos em Canudos e demais áreas dos sertões nordestinos enquadram-se no universo de sentidos e crenças compartilhados por Antônio Conselheiro e seus seguidores, e vice e versa. Ou seja, como a organização da vida material sertaneja, mormente no que diz respeito a sua cultura alimentar, moldou o discurso ideológico e identitário do arraial sertanejo. Procura-se, assim, contribuir para a compreensão do movimento liderado por Antônio Conselheiro, estabelecendo um quadro relacional entre instâncias, que, embora não se determinem, incidem com bastante força uma na outra, como é o caso da cultura e da alimentação. No debate acerca de Canudos, a evidenciação de tal relação torna-se bastante importante, em virtude do descuido com que os fundamentos culturais da base alimentar do arraial têm sido tratados.

Não está no escopo deste trabalho, obviamente, oferecer respostas definitivas para essa dimensão tão importante, em um momento tão crucial da História do Brasil. A aspiração deste texto é evidenciar a complexidade da questão, a partir de uma premissa central - a de que os seres humanos recorrem aos seus aparatos culturais para satisfazerem suas necessidades, as quais passam a agregar significados que vão além da materialidade. Desse modo, explorar as práticas alimentares de Antônio Conselheiro e seus seguidores permite um vislumbre do universo de sentidos que permeava o cotidiano daquela comunidade.

\section{UMA PERSPECTIVA EMERGENTE DE ANÁLISE}

Canudos constituiu, no final do século XIX, singular experiência de trabalho e produção coletivos, os quais já vinham se desenvolvendo desde o período de peregrinação de Antônio Conselheiro. Porém, no arraial do Belo Monte, onde aos antigos seguidores do Conselheiro somaram-se milhares de sertanejos, essa tendência de ação coletivista ganhou vulto de uma experiência social destoante do sistema produtivo vigente nos sertões de então, no qual a propriedade da terra figurava como uma premissa elementar das relações de poder político e econômico.

Em Canudos, a propriedade privada de bens individuais era reconhecida, excetuando a terra, a qual era disponibilizada para aqueles que dela quisessem e pudessem ${ }^{1}$ tirar o seu sustento (ARRUDA, 2006). Essa configuração social, fortemente amparada nas premissas religiosas do povoado, permitiu que a comunidade crescesse, abrigando famílias sertanejas que fugiam do jugo opressor dos latifundiários, além de negros recém-libertos e de indígenas das redondezas (MELLO, 2014).

Sobre os indígenas, Reesink (2012) destaca o grande afluxo da etnia Kiriri, da localidade de Mirandela, para o arraial conselheirista. A tradição oral ligada a esse povo revela que a possibilidade de juntar-se ao seguidores de Antônio Conselheiro era recebida com alegria pelos indí- 
genas, que faziam da peregrinação a Canudos um momento de regozijo e partilha com as gentes do sertão: "Não levaram nada para comer, mas sempre eram bem recebidos por onde passavam, era uma santa alegria até Canudos" (REESINK, 2012, p. 246).

Conforme Arruda (2006), a comunidade mantinha contato com os povoados circunvizinhos, servindo de "modelo para a população que vivia fora da comunidade", dando "provas concretas que os sertanejos podiam encontrar formas alternativas e autônomas de vivência social baseada na solidariedade e na fraternidade" (ARRUDA, 2006, p. 152). Assim, Canudos desponta como uma contraposição ao sistema calcado no latifúndio, constituindo um padrão de sociedade adaptado ao meio sertanejo, tanto no que se refere à dimensão inclusiva, quanto no que diz respeito à constituição de meios próprios de subsistência. Estes pautavam-se por uma dinâmica de relação complexa com o ambiente exterior à comunidade, que tanto abrangia a produção necessária à manutenção da comunidade, quanto a importação de víveres e objetos diversos, muitas vezes sob a responsabilidade de emissários do Conselheiro.

Esse modelo de sociedade projetou-se para além das fronteiras de Canudos, servindo de referência para aqueles que enfrentam a luta pela terra, pela afirmação de pautas identitárias, ou mesmo pelo exercício da liberdade religiosa e de crença. Nesses embates, a memória de Canudos foi se constituindo em patrimônio vivo, calcado na experiência de homens e mulheres reais, cuja luta desigual contra o poder dominante tem sido celebrada por meio de poemas, romances, cordéis e músicas, revelando um universo de representações que vai muito além das páginas de Os sertões, como a pesquisa de Ângelo (2002) revelou.

Nas páginas do "livro-monumento" de Euclides da Cunha, esses homens, de vez que o autor se jactava de não tratar de mulheres em suas obras (MELLO, 2014), adquiriram as feições de uma estatuária heroica, porém, estática. Todavia, o legado da comunidade do Conselheiro é dinâmico, foi-se formulando no calor dos embates, adaptando-se a novas condições discursivas, instituindo novas perspectivas e temas de interesse.

$\mathrm{Na}$ esteira dos múltiplos embates e batalhas simbólicas, o tema da alimentação tem adquirido destaque, revelando muito da história de Canudos e de como a gente do Conselheiro procurou construir, à sua maneira, uma comunidade autônoma, alicerçada na experiência e na fé das populações sertanejas. Nesse contexto, é bastante relevante tratar do repertório alimentar característico dos sertões nordestinos, frente ao qual a comunidade procurava não apenas organizar a sua vida material, mas também promover para as populações vizinhas as virtudes do seu arraial santo, o qual garantia a todos quantos lá chegavam o alimento necessário e apreciado.

Estão presentes, nos relatos acerca de Canudos, alguns elementos bastante comuns do patrimônio alimentar dos sertões. A farinha, qua- 
se onipresente nas refeições sertanejas; o milho, junto ao seu parceiro ideal, o leite - composição que origina receitas bastante apreciadas pelos sertanejos, como a canjica, a pamonha, o mugunzá; o umbu, que serve para o preparo da umbuzada, sobremesa bastante louvada por Euclides da Cunha; o café; o mel de abelha; a rapadura; o jerimum; o melão, a melancia, o feijão, a fava e, obviamente, a carne, decorrente daquela que é largamente apontada como a principal atividade econômica da região, a pecuária, tanto bovina, quanto caprina.

Contudo, a história de resistência, contada a partir da alimentação em Canudos, não se resume ao cardápio da dieta sertaneja. Tão importante quanto os componentes dessa alimentação é a forma como a comunidade se organizava em torno destes, compondo um conjunto de práticas e convenções que apontam as particularidades da comunidade, posto que "cada hábito alimentar compõe um minúsculo cruzamento de histórias" (CERTEAU; GIARD; MAYOL, 2013, p. 234). Desse modo, as práticas em torno do alimento em Canudos sinalizam tanto as diversas influências que compuseram o dia a dia da comunidade, quanto o esforço desta em inserir-se na realidade que a rodeava.

Tal compreensão acerca dos hábitos alimentares fornece subsídios para o confronto com as seguintes questões: como enquadrar os rigorosos jejuns, evidenciados em uma gama de relatos acerca de Canudos? Não seriam tais práticas reações insubmissas a uma realidade hostil? Nessa perspectiva, há que se considerar os valores sobre os quais estava assentado o arraial de Canudos. O que viabilizava aquela vivência comunitária passa pelo sistema de crenças e pelos anseios morais daquela coletividade. Nesse sentido, ser viável não se restringe apenas à obtenção de recursos para a subsistência, mas agrega significados à vida material, tendo em vista as expectativas e motivações da população ante seus desafios cotidianos. É significativo, nesse sentido, o que é ressaltado por Reesink acerca do que teria motivado os Kiriri de Mirandela a aderirem ao movimento conselheirista. Uma motivação que era partilhada com os demais grupos sociais que se reuniram em torno do Conselheiro, como bem aponta o referido autor:

$\mathrm{Na}$ verdade, quase todas as categorias sociais, reconhecidas socialmente ou construídas pelo analista, estavam presentes em Canudos, com a provável exceção ou presença mínima de grandes proprietários. Uma vida melhor os atraía, principalmente uma vida mais justa, mas não em razão somente de uma organização social mais legítima, mas porque esta ordem sociocultural se fundamentava na ordem englobante e fundante da religião, numa variante de catolicismo que fundamenta uma ordem moral e geral do mundo e do socius (REESINK, 2012, p. 248).

Nesse contexto, o tema da subsistência supera os limites das necessidades básicas, alcançando também uma fundamentação moral que, de forma alguma, está alheia às demandas concretas da população, não sendo, portanto, um mero recurso de "fuga". Pedro Vasconcellos (2017) 
ressalta como o conteúdo religioso do arraial de Canudos, mesmo em seus aspectos restritivos, auxiliou a comunidade na superação de dificuldades materiais, a partir de concepções que, para o conjunto da população sertaneja da época, não eram, de forma alguma, extravagantes.

Assim, a consciência do limite, evidente no conjunto das meditações/ prédicas que formam os Apontamentos... [manuscritos subscritos pelo Conselheiro], não resultou num descaso para com a mesma vida cheia de precariedades; pelo contrário estimulou a que estas fossem enfrentadas coletivamente; mais ainda: que as formas do viver organizadoras dos trabalhos e dos dias recuperassem a densidade escatológica que a pregação católica convencional da época de alguma forma lhes havia retirado (VASCONCELLOS, 2017, p. 198).

Superando, assim, a caracterização vaga e depreciativa de "fanática", a religiosidade canudense revela-se significativamente comprometida com a realidade, buscando nesta as suas referências e os seus parâmetros de ação. Tanto é assim, que Vasconcellos aponta como as prédicas de autoria de Antônio Conselheiro, revelando suas concepções religiosas, eram modificadas a partir de dados da realidade. Segundo esse autor ${ }^{2}$, que reuniu e publicou um caderno de prédicas de Antônio Conselheiro, Apontamentos dos Preceitos da Divina Lei de Nosso Senhor Jesus Cristo, para a Salvação dos Homens, o arraial de Canudos, com sua configuração social tão peculiar quanto dinâmica, exigirá que o líder religioso cearense reelabore algumas de suas perspectivas religiosas, contrariando, assim, a imagem do fanático intransigente. "É justamente o Belo Monte que proporciona ao Conselheiro a possibilidade de reelaborar dados básicos, constitutivos do universo religiosos que deu norte a sua existência” (VASCONCELLOS, 2017, p. 198).

Josué de Castro trata da relação entre as práticas religiosas desenvolvidas em Canudos e a realidade material da população sertaneja, em uma perspectiva que aborda a associação de causa e consequência entre fome e "fanatismo". Porém, é possível vislumbrar uma alternativa a essa ideia a partir da constatação de que os relatos acerca dos rigorosíssimos jejuns praticados pelo Conselheiro "encontravam eco no espírito da coletividade já acostumada aos martírios da fome" (CASTRO, 2007, p. 239). Esta citação revela a imersão do pregador no ambiente em que atua, a qual confere não só uma dimensão de determinação religiosa, mas também de interação às práticas do jejum.

Essa simples afirmação do autor de Geografia da Fome vai ao encontro de dados que revelam um Antônio Conselheiro que moldou sua prática apostolar a partir da vivência com os dramas cotidianos da população, que negociava com os poderes constituídos no sertão, que estava atento às perspectivas abertas aos seus seguidores e que, sobretudo, agia no sentido de mitigar os sofrimentos da população. Ação essa que não se inicia com a fundação de Canudos, em 1893, apenas quatro anos antes da morte do Conselheiro. Pelo contrário, o arraial dizimado 
pela República resultou de toda a experiência acumulada pelo religioso cearense e seus seguidores, após anos de peregrinação pelos sertões nordestinos, erguendo igrejas, muros de cemitérios, tanques de água e até mesmo povoados. Basta mencionar, como o faz José Calasans (1998), que Antônio Conselheiro é o fundador do povoado que originou a cidade de Crisópolis, na Bahia, onde até hoje está erguida a igreja do Bom Jesus, construída sob a liderança de Conselheiro.

\section{O MANÁ SERTANEJO}

No relatório que elaborou acerca de sua missão religiosa no arraial de Canudos, em 1895, o Frei João Evangelista de Monte Marciano, que fora incumbido de dissuadir a população sertaneja de seguir Antônio Conselheiro, registra a maneira como os sertanejos procuravam arregimentar mais pessoas para as fileiras conselheiristas. Segundo Frei João Evangelista, assim os sertanejos de Canudos promoviam o seu arraial: "ali, porém, nem é preciso trabalhar, é a terra da promissão, onde corre um rio de leite, e são de cuscuz de milho os barrancos" (MARCIANO, 1987).

A propaganda sertaneja, em que pese o olhar parcial de Frei João Evangelista, distingue a sua comunidade justamente a partir de referências alimentares, as quais aludem tanto ao acesso ao alimento, quanto à sua composição. Assim, essa mistificada descrição de Canudos encontra eco, por exemplo, nas constatações de Josué de Castro acerca da dieta sertaneja, na qual o milho, elemento base dessa dieta, anda de par com o leite, suprindo as necessidades nutricionais das populações dos sertões (CASTRO, 2007). Nesse caso, fica patente a relação entre a composição material do cotidiano sertanejo e o ideário canudense, que se beneficia dessa dimensão.

Cabe observar que essa descrição, na qual o território de Canudos figura como uma grande refeição sertaneja, fala de um tempo presente, não de um reino de prosperidade que está por vir. Assim, essa descrição, além da clara referência religiosa que faz, sugere também o regime econômico e social desenvolvido em Canudos, no qual o alimento estaria acessível a todos que ingressassem na comunidade. José Calasans (1950) inclui esse trecho do relato de Frei João Evangelista entre os vários rumores de milagres praticados pelo Conselheiro, que circulavam pelos sertões.

No entanto, o relatório do Frei Evangelista, que serviu de referência inclusive para Euclides da Cunha, é menos importante para a compreensão do cotidiano do arraial conselheirista do que o é para um vislumbre das tensões que envolviam a comunidade sertaneja e as elites clericais e políticas de então. O tom apaixonado do relato, no qual o seu autor conclui pela necessidade de uma intervenção estatal em Canudos, revela momentos em que as diferenças de posicionamentos entre o Frei missionário e os sertanejos parecem rumar para um desenlace com sérias consequências. 
É notável como, em alguns desses momentos mais tensos, o tema da alimentação surge como protagonista, quer seja quando o Frei cobra do Conselheiro pela pobreza e pela fome que vitima os sertanejos de Canudos, "entregues à ociosidade" (ou seja, distantes do regime econômico predominante), ou quando o membro do clero católico procura convencer os seguidores do Conselheiro de que é possível jejuar sem os rigores que se praticavam em Canudos. O Frei não deixa de registrar, nos dois momentos, as sonoras discordâncias da população.

A tensão entre a missão capuchinha e os conselheiristas revela os atritos que já existiam entre o Conselheiro, seus seguidores e as autoridades eclesiais. Todavia, tal conflito não pode ser resumido a uma tendência sediciosa, por parte de Canudos, em relação à Igreja. Conforme Vasconcellos (2017) aponta, são diversas as passagens do caderno de prédicas assinado por Antônio Conselheiro que sinalizam a necessidade da "ação sacerdotal" para a obtenção das "graças divinas". Essa compreensão não ficou restrita aos sermões do religioso cearense, uma vez que a comunidade recebia a visita regular de certo padre Vicente Sabino dos Santos que, segundo o conselheirista Honório Vilanova (apud VASCONCELLOS, 2017), saía do arraial com "a bolsa regalada", depois de ministrar os santos sacramentos para o povo do Conselheiro.

O próprio Frei João Evangelista realiza sua missão com a anuência do Conselheiro, ainda que este tenha se mantido bastante desconfiado ante as pregações do capuchinho, que não escondia o seu intuito de desestruturar o arraial conselheirista, no que atendia as recomendações da alta cúpula católica da Bahia, na pessoa do arcebispo Dom Jerônimo Tomé. Cabe ressaltar, também, que as celebrações religiosas, ministradas por Frei João, contavam com uma grande audiência. Esta, contudo, não titubeou em manifestar-se em favor dos ensinamentos de Antônio Conselheiro e, consequentemente, contra os propósitos da missão capuchinha, a qual foi abortada antes do prazo, com apenas sete dias.

A atitude da gente do Conselheiro em relação à missão capuchinha revela, por um lado, uma postura de reconhecimento dos dogmas e da estrutura da Igreja católica, a qual gozava de grande precedência sobre os moradores do arraial. Por outro lado, o catolicismo popular sertanejo, do qual o movimento de Canudos é uma expressão, dispõe de seus próprios agentes e manifestações, os quais se expressam, muitas vezes, à revelia das orientações da Igreja. À época de Canudos, a Igreja Católica no Brasil passava pelo que Della Cava (2014) denominou de "romanização", ou seja, por um processo de normatização do credo católico, a partir das diretrizes centralizadoras de Roma, que resultou em uma maior repressão às expressões de religiosidade espontâneas.

Diante desse complexo quadro, no qual a comunidade religiosa busca autonomia sem perder de vista o alinhamento com as bases do credo católico, é bastante elucidativo que os hábitos de alimentação tenham se tornado elementos cruciais na contenda entre o representante da cúpu- 
la da Igreja e os adeptos do conselheirismo. A própria centralidade das práticas de alimentação, na comunidade de Canudos, já revela uma aproximação entre o Conselheiro, seus seguidores e a doutrina cristã, pois, como afirma Ponnau (2006, p. 109), "o Evangelho é uma grande refeição".

Mesmo na pregação de Frei João Evangelista, na qual se sobressai o tom condenatório sobre a doutrina pregada pelo Conselheiro, essa aproximação se insinua, na medida em que, ao condenar os rigores dos jejuns praticados em Canudos, o capuchinho não descarta a importância da abstinência alimentar. Todavia, é a partir dessa base religiosa que a comunidade irá procurar se distinguir da sociedade ao seu redor, e, em certa medida, da própria Igreja, uma vez que esta, em seu alinhamento com os poderosos da República, estaria se desviando da verdadeira fé cristã, como aponta Vasconcellos:

Aos olhos do Conselheiro e de sua gente, é a Igreja Católica que está mudando: a maior evidência disso é a adesão que muitos de sua hierarquia estão dando ao nefasto regime republicano, bem como a hostilidade manifesta às expressões tradicionais da devoção (VASCONCELLOS, 2017, p. 164).

Assim, a comunidade ressignifica alguns hábitos e crenças alimentares comuns do catolicismo, tendo em vista não apenas maior fervor religioso, mas também visando manifestar, de modo coerente, os seus posicionamentos. Desse modo, em Canudos, às interdições alimentares frequentes no catolicismo, como a ingestão de carne e o consumo de álcool (CUNHA, 2016), irão se somar outras, sinalizando o posicionamento da comunidade frente àqueles vistos como inimigos do povo de Deus (ainda que fossem mui amigos do arcebispo). Da mesma maneira, aos prodígios alimentares narrados na Bíblia e na tradição católica, serão acrescentados os milagres do Conselheiro, aliviando a fome das populações sertanejas, as quais não figuravam propriamente como alvos para promoção de milagres, na compreensão de uma cada vez mais romanizada Igreja Católica. Ainda assim, como bem destacou a pesquisa de Calasans (1950), eram muitas as notícias que circulavam pelos sertões de milagres atribuídos ao Conselheiro.

No cristianismo, as notícias de milagres envolvendo a multiplicação de alimentos, como aquele que foi atribuído à Antônio Conselheiro, com a criação de uma comunidade em que são de cuscuz de milho os barrancos, não são novidades. Muito pelo contrário, o Evangelho traz vários relatos de prodígios, nos quais os pães, os peixes e até mesmo o vinho são ofertados a um grande número de pessoas, que, sem as manifestações milagrosas, não teriam o que comer ou beber. Na realidade, tomando-se em consideração a cultura judaica, da qual o cristianismo se origina, a proliferação sobrenatural de alimentos, que, tal como em Canudos, ocupariam o lugar da própria terra, remeteria a narrativas que procuram estabelecer as origens do povo hebreu na "terra santa", que “emana leite e mel". 
Contudo, a imagem de um solo que é, todo ele, uma grande refeição, pode guardar um significado mais restritivo do que a multiplicação ilimitada de alimentos pode sugerir. Isso porque, a exemplo da terra prometida do velho testamento, a terra constituída de comida indica não apenas a prosperidade da comunidade fixada nas "barrancas de cuscuz", mas também a própria santidade, originadora da fartura. Nesse sentido, Douglas (2010) ressalta como, no texto bíblico, a fertilidade, do ventre ou da terra, revelam a intercessão divina: "o gado, tal como a terra habitada, recebe a bênção de Deus, torna-se fértil e integra-se na ordem divina" (2010, p. 44), ou ainda, a "graça divina torna a terra fértil e, portanto, a vida dos homens possível" (2010, p. 41).

Cabe, contudo, pontuar que o caráter restritivo anteriormente citado decorre da própria raiz da palavra santidade, a qual, segundo Douglas (2010, p. 40) significa "separar (set apart)". Ser santo é, portanto, ser diferente, é estar à parte, como a terra de cuscuz de milho em meio à caatinga. Na narrativa bíblica, tal significado fica bastante evidente nas circunstâncias em que os israelitas se esforçam por manter uma identidade cultural frente aos diversos povos com os quais entram em contato. Outro não é o cenário que se apresenta no momento da elaboração do Levítico, livro que contém um extenso repertório de interdições e normas alimentares, visando, justamente, a instituição de um povo santo. "Sejam santos, porque eu, Javé, o Deus de vocês, sou santo" (Lv 11:45). Tal recomendação surge no momento do exílio dos israelitas na Babilônia, ou seja, em uma circunstância não apenas de contato, mas de grande imersão em outra cultura.

$\mathrm{Na}$ Canudos de Antônio Conselheiro, ainda que não se observe o mesmo ímpeto de preservação nacional, a partir das instruções de um Deus identificado com uma nação específica, é perceptível a utilização do alimento na composição de uma identidade santa, em oposição a um ambiente degradado pelo pecado. De uma maneira geral, tendo em vista práticas e discursos recorrentes na tradição ascética do cristianismo, essa busca por santidade, a partir do alimento, ou antes pela privação deste, está bastante presente nas práticas de jejuns, que visam superar o mundo da matéria, contaminado pelo pecado.

Ora, observando-se o próprio exemplo da Canudos, ou, mais precisamente, a trajetória de Antônio Conselheiro, cujas práticas ascéticas impressionavam as populações sertanejas por seu rigor, é possível observar que mesmo a privação do alimento, tendo em vista a superação do mundo material, contribui por moldar essa realidade. Nesse sentido, pode-se dizer que, da mesma forma que um jantar pode engendrar maior contato entre as pessoas que compartilham da refeição servida, a prática do jejum visa, também, uma intensa comunhão com Deus. Ou seja, uma postura negativa e de recusa, revela-se, na verdade, como uma ação criadora de laços, entre o ser humano e a divindade. Mas não apenas entre eles. 
Conforme anteriormente ressaltado, os jejuns do Conselheiro ecoavam sertão a fora, transmitindo uma mensagem de afinidade entre o religioso e a sofrida gente dos sertões. Cabe ressaltar que, no imaginário popular, mais do que os efeitos de mortificação do corpo, o que ganha ênfase, nesses feitos do Conselheiro, é a vida, a possibilidade de se viver com pouco, o que resulta em um estímulo à solidariedade, como fica claro no relato de um milagre do Conselheiro, em que um "crente abastado", saindo de parca refeição que dividira com o religioso cearense, se sente "empanzinado". É significativo, nesse relato, que o alvo do milagre tenha sido alguém munido de recursos, o que deixa mais evidente o caráter didático da ação milagrosa. Segue a descrição da mesma, nas palavras de Euclides da Cunha (2016):

Conta-se que em certo dia foi visitado por um crente abastado das cercanias. Repartiu com ele a refeição escassa; e este - milagre que abalou o arraial inteiro! — saiu, do banquete minúsculo, repleto, empanzinado, como se volvesse de festim soberbo (CUNHA, 2016, p. 200).

\section{NOS PASSOS DO BEATO PEREGRINO}

Analisada atentamente, a trajetória de Antônio Vicente Mendes Maciel, o Conselheiro ${ }^{3}$, revela-se rica de táticas e de respostas criativas, que, de muitas formas, rechaçam a imagem do fanático inflexível, que se tornou o líder de dezenas de milhares de pessoas em virtude da histeria coletiva de um povo miscigenado, logo, "degenerado" (CUNHA, 2016). Canudos só fora possível, graças a um árduo trabalho do Conselheiro, na pregação religiosa, no empreendimento de obras pelo sertão e na construção e projeção de uma imagem de homem santo, para o que contribuiu muito a relação do líder religioso com o alimento.

Segundo Calasans (1950), a primeira notícia veiculada na imprensa sobre Antônio Conselheiro data de 1874, pelo menos dezenove anos antes do estabelecimento do líder religioso e seus seguidores na velha fazenda de Canudos. O jornal O Rabudo, da cidade Estância, em Sergipe, foi o emissor da notícia, que dava conta de um "santarrão", de aspecto "degradante", a "figura mais degradante do mundo", que gozava, no entanto, de grande prestígio entre as populações sertanejas, que, já naquela época, tratavam o religioso cearense como santo. A partir de então, Antônio Conselheiro tornou-se um personagem recorrente em periódicos e na comunicação entre autoridades, sendo retratado de maneira ambígua, despertando repulsa e admiração. Galvão (2015) destaca os traços mais frequentes nas descrições do Conselheiro:

Quando começou a chamar a atenção, Antônio Conselheiro já se tinha transformado num penitente ou, como passaria a assinar, "O Peregrino". Certos traços passarão a ser reiterados quando dele falam: seu tipo físico de sertanejo, com barba e cabelo compridos; o hábito azul de brim americano; a aparência desmazelada; o regime ascético, pelo qual se privava 
de carne, jejuava e dormia no chão; as obras de construção e restauração em que se empenhava; o carisma - e, naturalmente, o perigo para a ordem constituída (GALVÃO, 2015, p. 71).

Tanto o texto de O Rabudo, quanto as palavras de Galvão, revelam todo um trabalho junto à população, que fora mal captado pelas autoridades e pelas camadas letradas dos sertões nordestinos. O fato é que, quando das primeiras menções públicas à figura do Conselheiro, este já exercia uma notável autoridade sobre os sertanejos. Daí o choque causado não só pela aparência do religioso, mas também pela popularidade de que o Conselheiro já desfrutava. Contudo, uma análise que leve em conta não apenas a sua figura, mas também o chão em que ele pisou, pode explicar a sintonia que se estabeleceu entre Antônio Conselheiro e as populações sertanejas.

Para além dos singulares aspectos de sua aparência, o Conselheiro logrou notabilizar-se por suas ações e hábitos, inclusive os alimentares, como a síntese de Galvão revela. Como fazer de uma ação tão cotidiana, como o hábito de comer, uma marca de personalidade tão eminente, que se destaca mesmo em descrições bastante sucintas? Tal questão é ainda mais significativa levando-se em consideração que o hábito em evidência é, muitas vezes, uma recusa ao alimento, o que, em termos de visibilidade, deveria deixar o hábito de alimentar-se ainda mais recôndito.

Em primeiro lugar, é preciso ter em conta que essa recusa, tal como é praticada e compreendida, constitui um gesto de significado coletivo, semelhante à partilha de uma refeição. A manifestação coletiva da rigidez alimentar do Conselheiro ocorria mediante os sermões do religioso cearense, que "pregava os jejuns prolongados, as agonias da fome", bem como pela autoexposição do líder de Canudos, que "dava o exemplo fazendo constar, pelos fiéis mais íntimos, que atravessava os dias alimentando-se com um pires de farinha” (CUNHA, 2016, p. 200).

Ademais, pode-se pontuar que os rígidos hábitos alimentares do Conselheiro, embora chamassem bastante atenção, não constituíam algo totalmente exótico ao cotidiano religioso de um sertão atravessado pelos pés andarilhos de muitos beatos. Estes, motivados pela escassez de padres nos sertões nordestinos ${ }^{4}$ e pela obra do Padre Ibiapina, que instituíra, sem a aprovação de Roma, ordens femininas de beatas, e que fora, ele próprio, um modelo de ação religiosa nos sertões da segunda metade do século XIX, empenharam-se na construção e reforma de edificações religiosas e na promoção de uma rígida conduta cotidiana, marcada, entre outros aspectos, por prolongados jejuns. Nesse sentido, Pompa (2015, p. 119) ressalta: "muitos beatos eram peregrinos, viajando de povoado em povoado, mendigando comida: visitavam doentes, construíam capelas e cemitérios, puxavam terços, ensinavam benditos”.

Imerso no seio da população, o beato compartilha as dificuldades rotineiras das comunidades do interior do Nordeste brasileiro do último quartel do século XIX. Sua alimentação frugal, em parte, reflete as limi- 
tações alimentares das populações sertanejas, que o guarnecem dos parcos provimentos de que solicita. Segundo Mariz (apud MELLO, 2014), o Padre Ibiapina, em suas "incansáveis" andanças, valia-se da "alimentação seca do interior de então". Todavia, mesmo em um ambiente dotado de tão parcos recursos, no qual se configurou um regime alimentar que Josué de Castro (2007) denominou como "espartano", o beato se destaca pela sobriedade de sua alimentação. O escritor Sílvio Romero (apud CALASANS, 1950, p. 29) deu o seguinte testemunho acerca de Antônio Conselheiro, a quem "possivelmente conheceu", quando o religioso cearense estivera pela primeira vez em Sergipe: "Passou por Sergipe, onde fez adeptos. Pedia esmolas e só aceitava o que supunha necessário para sua subsistência, no que divergia dos nossos mendigos vulgares".

Essa diferenciação denota que, mesmo inserido na comunidade, o beato se destaca nesta, como uma espécie de figura à parte (um santo), sendo, muitas vezes, compreendido como um mediador, a partir do qual se estabelecem conexões com as instâncias sagradas. Esta parece ser a compreensão que figura em testemunhos de indivíduos que veem a presença de alguns desses religiosos como uma oportunidade singular de garantir os benefícios dessas ligações com o sagrado e alcançar o Reino dos Céus. Uma ocasião, de fato, única, como sugerem os seguintes trechos de cartas de moradores de Canudos, em material coligido por Calasans (2002, p. 7): “Agora aparece por cá uma noticia que o concelero diz que quem não for daqui até agosto que não hentra mais hentão eu lhe mando pedir a Vem [...\}". Ou ainda: "[...] faça por vir o mais breve que lhe seja possível, com sua família, pois a marca do Senhor já esta dada para os Christãos que quizerem gozar de sua Santa Companhia”.

O próprio Conselheiro reconhecia o seu papel de mediador entre a comunidade e as esferas sagradas. Segundo Vasconcellos (2017), o tema da salvação daqueles que o acompanhavam era uma preocupação constante para Antônio Conselheiro. Com tal objetivo em mente, ele não poupava esforços, mesmo que isso significasse uma vida de intensos sacrifícios:

[...] em meio a tantos fazeres, cuidando ao mesmo tempo da terra e do céu, da vida e da morte de tantos que lhe passam pelas mãos e lhe confiam as melhores esperanças e os mais ardentes temores, preocupado com a sua salvação eterna e a de todos quantos nele apostam [...] (VASCONCELOS, 2017, p. 21).

O beato levou uma vida de doação. Doação de tempo, trabalho, recursos e conselhos. Doação da própria vida, a qual entregou aos cuidados da comunidade, para que esta pusesse em prática a caridade necessária para a conquista da salvação. Nos sertões nordestinos, essa função associada ao hábito de dar esmolas é perceptível, por exemplo, na crença de que Jesus se disfarçava de mendigo para testar a bondade das pessoas. Crença que, segundo Câmara Cascudo, encontra-se presente em todo o sertão nordestino (CASCUDO, 1978). 
Assim, embora referente à outra vida, o caminho para o Reino dos Céus é construído nesta realidade e de modo coletivo. No caso de Antônio Conselheiro e seus seguidores, o impacto dessa convicção sobre a vida material da população foi considerável, contribuindo, conforme pontuou Vasconcellos (2017), para que as dificuldades diárias "fossem enfrentadas coletivamente". A presença do líder religioso, bem como a mensagem e o exemplo que este transmite, reforçam os laços de solidariedade da comunidade. Configura-se, assim, entre os conselheirista, uma "economia religiosa", calcada na ação cooperativa e solidária, que, nas palavras de um dos maiores opositores de Canudos, o Barão de Jeremoabo 5 , seria a "seita do fanatismo e do comunismo" (VASCONCELLOS, 2017, p. 155).

A "economia religiosa" que se instaura a partir da ação do beato cearense está assentada no chamado "cristianismo primitivo", ou seja, na organização das primeiras comunidades cristãs, as quais serviram de paradigma organizacional para muitos movimentos cristãos ao longo da História (ARRUDA, 2006). Em suas pregações, Antônio Conselheiro desenvolvia, de forma original, o tema da caridade e os seus benefícios, que não se restringiam somente às benesses espirituais:

Porque todo o próximo tem o direito natural para pedir e ser remediado. [...] Considerem o valor que tem a caridade diante de Deus, para não deixarem de praticá-la pelo incomparável bem que dela resulta (CONSELHEIRO, 2017 [1897], p. 87-88).

Em termos práticos e administrativos, Antônio Conselheiro não se descuidou desse potencial da caridade para o desenvolvimento de seus objetivos materiais. O líder religioso, já instalado em Canudos, chega a sistematizar a coleta de esmolas pelas comunidades próximas ao arraial por ele liderado. Para tanto, utiliza-se dos beatos formados a partir da devoção em torno da sua figura, o que reforça a tradição de beatos andarilhos sertanejos, da qual o próprio Conselheiro provém, bem como investe no papel associado a esses religiosos na promoção da caridade:

As esmolas eram obtidas pelos beatos do Conselheiro que saíam, devidamente autorizados, para pedirem, levando, não raro, cartas neste sentido. Antônio Conselheiro era um missivista humilde, que escrevera muitas epístolas solicitando dinheiro, bois, coisas outras de que "tinha precisão" (CALASANS, 2002, p. 14).

Galvão (2015) também dá notícias desses “emissários” do Conselheiro, pontuando o papel do líder de Canudos como administrador dos recursos coletados:

Alimentos, roupas e dinheiro eram recebidos em donativos pelo Conselheiro e repassado aos destituídos. Por toda a duração do arraial, emissários percorriam o sertão solicitando esmolas em espécie ou em numerário, o conjunto das quais era por ele administrado (GALVÃO, 2015, p. 73). 
Além de garantirem os almejados recursos, estabelecendo uma espécie de "previdência" para os mais necessitados da comunidade, essas esmolas e donativos reforçaram os elos de Canudos com as comunidades vizinhas, revelando que a fixação do Conselheiro e daqueles que o seguiam não significava o isolamento destes, nem tampouco um rompimento com o legado estabelecido a partir das andanças de Antônio Conselheiro. Assim, o beato peregrino continuava incentivando as populações sertanejas a participarem do grande banquete da caridade, quer estivessem em Canudos ou não.

\section{CANUDOS, CIDADE SANTA}

Canudos não era, de forma alguma, uma comunidade fechada, na qual meia dúzia de "fanáticos" esperavam o fim do mundo. Pelo contrário, o arraial estava aberto, tanto para aqueles que procuravam amparo espiritual, como fica claro, por exemplo, no Relatório de Frei João Evangelista, que afirma que a maior parte da audiência da missão dirigida pelo frade capuchinho era de "gente de fora", quanto para quem quisesse fazer transações econômicas com a gente do Conselheiro. As seguintes palavras de Mello (2014) denotam, inclusive, "certa pujança econômica" na comunidade conselheirista:

Depoimento recente, dado por ancião, filho de jagunço, ainda hoje residente na área, vai além na configuração da economia do Belo Monte, agregando a esta um caráter ativo, exportador, representado por contratos de fornecimento de peles de bode celebrados por Antônio Vilanova [maior comerciante do arraial e pessoa de confiança do Conselheiro] com os centros de Juazeiro e Feira de Santana (MELLO, 2014, p. 97).

Além de centro exportador, Mello (2014, p. 97) também ressalta que o arraial de Canudos era um grande importador de gêneros, "especialmente das localidades próximas: de Jeremoabo, de Tucano, de Uauá, de Várzea da Ema e até de Feira de Santana”. Cabe pontuar que esta última localidade, que figura tanto entre os importadores, quanto entre os exportadores de produtos para o arraial, dista mais de $250 \mathrm{~km}$ de Canudos. Fica patente, desse modo, o raio de influência da comunidade que se desenvolveu a partir da liderança religiosa de Antônio Vicente Mendes Maciel.

Contudo, apesar de integrada à economia sertaneja do período, a cidadela conselheirista buscava conservar uma identidade diferenciada do seu entorno, tal qual o beato que se insere na comunidade, estando à margem desta. No caso de Canudos, todavia, tal distinção refere-se não apenas a uma superação do mundo material, em razão de uma dimensão sagrada. Trata-se, pode-se dizer, de uma tomada de posição nesse mundo da matéria, ainda que tal posicionamento se baseie em argumentos religiosos. Nas palavras de Mello (2014, p. 88), o arraial estava "um pé dentro e outro fora também da realidade política e administrativa do país. No Brasil, sem ser Brasil”. 
Segundo a doutrina do Conselheiro, a República, instalada no Brasil em 15 de novembro de 1889, representaria a "lei do cão", uma afronta ao ordenamento instituído por Deus, que estabelecia uma hierarquia sagrada, na qual as autoridades constituídas são investidas de seus poderes pelo próprio Deus. Desse modo, Dom Pedro II e seus herdeiros teriam um direito sagrado ao posto de Imperador do Brasil.

A instalação do Conselheiro e de sua gente, numa então velha e decadente fazenda de uma localidade conhecida como Canudos, em 1893, ocorre após violentos embates entre os conselheiristas e as forças policiais. Estas, representando as elites econômicas e política dos sertões, atacaram o peregrino e seus seguidores no lugar de nome Masseté, após Antônio Conselheiro haver liderado, em um "lapso de oito dias", "uma queima de tábuas com os editais dos novos impostos republicanos, os quais, como é óbvio, viriam sobrecarregar de gravames a economia de penúria dos pobres" (GALVÃO, 2015, p. 71).

Assim, percebe-se que a hostilidade à República, bastante presente nas pregações de Antônio Conselheiro, encontrava eco no dia a dia das populações sertanejas, que penavam ante o arrocho fiscal republicano. E ainda assim, se o discurso antirrepublicano do Conselheiro fugisse à compreensão da comunidade, a polícia a fazia compreender, com as constantes perseguições empreendidas ao povo do Conselheiro.

Desse modo, a comunidade de Canudos se forma em um contexto de repressão, no qual a fixação em um lugarejo remoto pode ter significado uma estratégia de sobrevivência. Arruda (2006), inclusive, aponta que a localização do arraial foi estrategicamente escolhida, visando a defesa da comunidade ante as investidas das forças policiais. Contudo, $\mathrm{o}$ arraial não se resumiu a um esconderijo. Na comunidade que fundavam, Antônio Conselheiro e seus liderados procuraram organizar uma sociedade a partir das suas visões de mundo, tendo em vista a forma como se viam dentro da realidade sertaneja do final do século XIX, no que, obviamente, incidia a hostilidade demonstrada, contra eles, pelas autoridades republicanas.

Assim, Canudos seria uma trincheira de santidade em uma terra maculada pelo pecado. A República, símbolo de degenerescência, não era reconhecida pelos canudenses. O próprio Conselheiro, conforme consta no Relatório de Frei João Evangelista Marciano (1987 [1895], p. 7), deixa isso muito claro, em sua justificativa sobre o motivo de manter homens armados no arraial - "No tempo da monarquia deixei-me prender, porque reconhecia o governo; hoje não, porque não reconheço a Republica”. A lei do arraial era a lei do Conselheiro, a qual, por sua vez, representava a vontade de Deus. É significativo, nesse sentido, que o tema principal do livro de prédicas do Conselheiro fosse justamente os dez mandamentos bíblicos. Assim, os seguidores do Conselheiro se viam mais próximos de um Reino dos Céus do que da República do Brasil. 
Sendo o arraial atravessado por diversas estradas, Canudos conheceu um significativo crescimento populacional, chegando a abrigar a segunda maior população da Bahia, com pessoas oriundas de, pelo menos, quatro estados, Sergipe, Ceará, Pernambuco e Bahia (MELLO, 2014). Diante disso, são perceptíveis alguns esforços, por parte da comunidade em estabelecer marcações identitárias, que firmassem os limites entre conselheiristas e republicanos. Nesse caso, ser republicano não significava apenas estar fora do arraial, mas comungar dos ideais republicanos, ter alguma participação nas instituições do novo regime ou, no decorrer da guerra, envolver-se a favor das tropas federais. Calasans (2002, p. 16), por exemplo, colheu a informação de que, aos recém-chegados na comunidade, era oferecido um pedaço de terra, "desde que não houvesse dúvidas quanto às suas convicções monarquistas e católicas."

Para a construção dessas configurações identitárias, referentes tanto aos conselheiristas quanto aos "republicanos, maçons e protestantes", ou seja, àqueles tidos como inimigos do arraial, irão contribuir determinadas atitudes em face de alimentos tidos como provenientes da República. José Calasans (1950) revela um incidente bastante elucidativo acerca dessa postura. Segundo o historiador sergipano:

Um carregamento de farinha foi apreendido pelos jagunços. Seu condutor, acusado de republicano, esteve ameaçado. [...] O homem defendeu-se. Ele não era republicano, sua farinha sim. Foi o bastante. Lançaram fora toda a carga. Era melhor passar fome do que aproveitar alimentos republicanos (CALASANS, 1950, p. 17).

Tal acontecimento é revelador de um grande esforço de manter-se em firme oposição a tudo que estivesse associado à República. A rejeição ao alimento, certamente, confere maior relevo a tal posicionamento, uma vez que o drama da fome, apontado como uma escolha mais aceitável do que o consumo da comida republicana, estava, de fato, sempre à espreita nos sertões nordestinos. Ademais, cabe pontuar que o alimento destruído pelos conselheiristas, no exemplo em questão, era a farinha, um elemento básico da dieta sertaneja, o qual poderia ter sido aproveitado pela gente necessitada de Canudos.

José Calasans, que colheu o exemplo em questão, enfatiza a destruição do alimento republicano, a partir dos recorrentes argumentos que associam a postura antirrepublicana dos conselheiristas a uma "incapacidade mental" de aceitar o regime que se instalara em 1889. Em suas "mentalidades arcaicas", os seguidores de Antônio Conselheiro teriam atacado a República a partir de uma religiosidade primitiva, a qual moldava toda a compreensão que tinham da realidade. "Tudo que fosse republicano recendia a pecado" (CALASANS, 1950, p. 17). A destruição de alimentos representaria, na interpretação de Calasans, uma prova categórica do "fanatismo" dos conselheiristas. "O fato é sintomático. Por si só serve para caracterizar a mentalidade contra a qual se arremessaram violentos os representantes da cultura litorânea" (CALASANS, 1950, p. 17). 
Parece certo que, no ambiente sertanejo, tal desperdício de alimento seja um ato extremo. Contudo, ao contrário do que supõe Calasans, uma atitude tão incisiva pode indicar a dimensão do esforço dos conselheiristas em ordenar, a partir de suas convicções, a realidade em que viviam, a qual encontrava-se francamente ameaçada pelas autoridades, de quem, de uma maneira geral, se espera algum amparo, em vez de hostilidade.

Desse modo, tachar como impuro aquilo que vem da República pode significar uma maneira de reestabelecer uma ordem ou uma organização, com seus elementos devidamente dispostos, o que, no caso dos sertanejos de Canudos, pode presumir não só a precedência de Deus sobre todas as coisas, seguido de um Imperador, mas também o reconhecimento da função de proteção associada às autoridades públicas. Função que vinha, de maneira muito evidente, sendo infringida em relação aos conselheiristas. Sobre a forma com as pessoas lidam com aquilo que seria impuro, Douglas (2010, p. 6-7) assevera: “A impureza é uma ofensa contra a ordem. Eliminando-a, não fazemos um gesto negativo; pelo contrário, esforçamo-nos positivamente por organizar o nosso meio".

Existem outros relatos de destruição de víveres, praticados por seguidores de Antônio Conselheiro, nas imediações de Canudos. Algumas dessas informações, contudo, partem das elites agrárias locais, interessadas em disseminar um clima de pânico em relação aos conselheiristas. Assim, tais narrativas estão inseridas em uma trama de boatos, com claras motivações políticas, que buscam mobilizar o medo que se construiu em relação aos habitantes de Canudos a favor de interesses partidários. É o que se observa na correspondência endereçada ao Barão de Jeremoabo, da parte de seus sequazes políticos. Uma dessas cartas, assinada pelo Tenente-Coronel Marcelino Pereira de Miranda, que se identifica como compadre e amigo do Barão, traz a seguinte notícia:

Dirigiram-se ao armazém onde estavam os víveres do Governo, puxaram para a rua e puseram fogo, que ainda continua a arder, muita farinha, milho, feijão, sacas de café e tudo mais. [...] Foram à fazenda Araçás do Dedé aí deitaram fogo na casa e cercas e soltaram cento e tantas reses do governo... (MIRANDA, 2001 [1897]).

As missivas endereçadas ao Barão tratam de supostas depredações praticadas pelos conselheiristas contra os proprietários de terras da região. Estes temiam que suas propriedades fossem saqueadas e depredadas pelos "fanáticos". Medo que parecia infundado, dado que o Conselheiro pregava "o respeito total à propriedade privada" (SAMPAIO, 2001, p. 59), como fica evidenciado em uma das cartas destinadas ao Barão de Jeremoabo, escrita após a destruição de Canudos. Nessa carta, o Juiz Federal Paulo Fontes, pertencente ao grupo político do Barão, noticia uma ação que movia contra a União, dado os prejuízos no seu rebanho, causados pelas tropas federais, e não pelos jagunços, que, segundo o magistrado, não se valiam de "bens republicanos". 
Eu peço indenização não é dos gados que os jagunços comeram, pois v. bem sabe que os conselheiristas não se utilizam dos bens republicanos, contando com os grandes recursos fornecidos pelos seus fanáticos, e sim dos que foram consumidos pelas forças legais, quando naquelas longínquas paragens viram-se baldos de recursos e perseguidos por horrorosa fome (FONTES, 2001 [1899]).

Em suas correspondências destinadas ao Barão, o juiz Paulo Fontes revela-se bastante apreensivo, em virtude dos boatos em relação às ações dos conselheiristas e da proximidade de suas terras com o arraial de Canudos. Incitado pelo medo, o juiz federal prevê: "o que eu sei é que eu serei o mais prejudicado” (FONTES, 2001 [1896]). Ademais, Paulo Fontes, como aliado de primeira ordem do Barão Jeremoabo, de quem era primo, pertencia a um grupo político que, bem antes da primeira expedição à Canudos, em 1896, já clamava pela destruição do arraial. Tanto é assim, que, ao referir-se aos preparativos da expedição de Moreira César, o juiz sustenta que a destruição do reduto conselheirista poderia ter sido realizada bem antes, poupando muitos recursos.

Ainda assim, apesar da proximidade de suas terras com Canudos e de um posicionamento político que o colocava, para os conselheiristas, entre os "republicanos", o juiz federal Paulo Fontes não teve suas propriedades violadas pelos "jagunços do Conselheiro". Fato ratificado por Vital Soares, que viria a ser governador da Bahia, e que atuara como advogado de Fontes no processo que este moveu contra União. Sobre a atuação de Soares na defesa dos interesses de Fontes, Sampaio (2001, p. 80) afirma: “[...] Vital Soares enfatiza que não pediria ressarcimento de danos causados pelos jagunços do Conselheiro, porque estes não haviam cometido dano algum a propriedades privadas".

Diferentemente da propriedade defendida pelo Juiz Paulo Fontes, o fragmento da carta de Marcelino Pereira de Miranda traz notícias de ataques a suprimentos do "governo", que há poucos dias havia organizado um fragoroso ataque contra Canudos, a fatídica expedição Moreira César. Já se contavam em três o número de expedições enviadas para destruir o arraial conselheirista, em uma crescente demonstração de força e beligerância. Nessas lutas deflagradas em solo baiano, como em muitos outros conflitos armados, as provisões de alimentos constituíram um ponto fundamental no desfecho das ações militares. Nesse contexto, os dois lados procuraram atacar as chamadas "munições de boca" de seus oponentes, o que, provavelmente, foi o que os conselheiristas buscaram fazer nos armazéns do governo, tal como Marcelino de Miranda informa.

Todavia, cabe notar que, tanto na carta de Miranda, quanto na de Fontes, os conselheiristas obedecem a um mesmo preceito, o da interdição de produtos associados aos republicanos. Mesmo quando tencionam atacar os estoques de víveres republicanos, os sertanejos de Canudos não se valem dos alimentos armazenados, sendo preferível destruí-los 
(ou soltá-los, no caso do gado) a consumi-los. A missiva do Juiz Fontes, inclusive, indica como esse procedimento dos conselheiristas, em relação aos "bens republicanos", é de amplo conhecimento na região, constituindo um aspecto determinante da identidade dos "fanáticos", que os diferenciava dos combatentes da República.

Essa distinção não decorre apenas de uma atitude visando confrontar a república, mas também de uma preocupação, por parte dos conselheiristas, com o que consumiam, tendo em vista uma concepção de impureza associada aos bens republicanos. Como lembra Douglas (2010, p. 8) acerca das noções de poluição corporal, "o processo de ingestão pode representar a absorção política”, e é significativo, nesse sentido, que entre os "bens republicanos" interditados aos conselheiristas estivessem incluídos os alimentos, mas não as armas. O seguinte trecho de Os sertões revela como o armamento deixado pela derrotada expedição Moreira César foi aproveitado pelos conselheiristas. Estes, ao mesmo tempo, rejeitavam as vestimentas republicanas, que "lhes maculariam a epiderme de combatentes sagrados".

[..] substituíram nas mãos dos lutadores da primeira linha as espingardas velhas de carregamento moroso pelas Mannlichers e Comblains fulminantes; e como as fardas, cinturões e bonés, tudo quanto havia tocado o corpo maldito das praças, lhes maculariam a epiderme de combatentes sagrados, aproveitaram-nos de um modo cruelmente lúgubre [...] (CUNHA, 2016, p. 346).

Da República, só poderia vir a morte, ou os instrumentos desta. A vida e os recursos necessários para a sua manutenção não passavam pelo crivo republicano. A carta do Juiz Paulo Fontes evidencia que a rejeição aos provimentos republicanos só fora possível em virtude dos "grandes recursos" viabilizado pelos "fanáticos", ou seja, por uma fonte de recursos estabelecida não em virtude do desprendimento dos conselheiristas em relação às condições materiais de existência, como sugerem os discursos que apontam a irracionalidade do fanatismo conselheirista, mas com o claro intuito de garantir a vida no arraial de Canudos. Assim, a repulsa aos alimentos republicanos está inserida em um quadro maior que revela todo um esforço em construir uma alternativa possível de vida, e não uma antessala da morte, na qual se espera, de maneira inerme e irrefletida, um iminente fim dos tempos.

\section{CONSIDERAÇÕES FINAIS}

Antônio Conselheiro e seus seguidores procuraram, a partir da experiência que adquiriram após quase vinte anos de andanças pelos sertões, construir uma comunidade que garantisse os meios de subsistência para aqueles que procurassem o amparo espiritual advindo do Conselheiro. Assim, a produção da vida material dos conselheirista estava bastante associada às crenças religiosas da comunidade, o que resultava na configuração de normas e preceitos que incidiam sobre as formas de subsistência do arraial. 
O alimento ocupa uma posição de destaque na cosmovisão cristã. O estabelecimento de preceitos alimentares tendo em vista a renúncia de uma materialidade corrompida, tem diversos precedentes no cristianismo, remontando às narrativas da tradição judaica. Antônio Conselheiro e seus seguidores se valeram do alimento como um vetor de afirmação identitária, estabelecendo limites entre a comunidade e a ordem social a que se opunham. Nesse sentido, o arraial sertanejo recorreu a um esquema de distinção social frequente na tradição cristã, sem perder de vista, contudo, as suas próprias especificidades doutrinárias, as quais, muitas vezes, iam de encontro às posturas oficiais da Igreja.

As normas alimentares desenvolvidas pelos conselheiristas não configuravam uma total alienação da realidade, como sugerem os discursos que enquadravam o Conselheiro e seus seguidores como "fanáticos". Na realidade, as regras estabelecidas não só estavam inseridas em uma moral que não era estranha às populações sertanejas, como relacionavam-se com as circunstâncias específicas da vida no arraial. É o que se pode observar na conduta dos conselheiristas em relação à República.

O caráter antirrepublicano da doutrina do Conselheiro, ainda que calcado em premissas religiosas, encontrava amparo nas impressões cotidianas das populações sertanejas, que se viram oprimidas pela tributação republicana. Além do mais, a forma como as autoridades governamentais lidavam com Canudos respaldava a pregação do Conselheiro contra o regime político recém-instaurado.

Nesse contexto, a rejeição a alimentos associados à República marca uma forma bastante incisiva da comunidade se afirmar contrária ao regime republicano. Tal forma de afirmação identitária também não perde de vista a perspectiva religiosa, sobretudo referente à tradição cristã, que encontra no alimento uma via recorrente de construção de uma identidade santa, em oposição a um degradado ambiente circundante.

O presente artigo procurou compreender o protagonismo das populações sertanejas no estabelecimento de parâmetros identitários consonantes às suas expectativas e experiências cotidianas, a exemplo das práticas alimentares. Nesse sentido, no lugar do controverso fanatismo, enfatizado por larga e diversa produção discursiva, o que se tem é o paulatino reconhecimento dos valores associados a uma comunidade que, apesar da franca hostilidade que a circundava, buscou viver e firmar o seu lugar na realidade social.

\section{NOTAS}

1. Aos incapacitados para o trabalho, a comunidade disponibilizava recursos que garantissem a sua subsistência, os quais eram arrecadados por meio dos donativos disponibilizados tanto pelas populações do entorno, quanto pelos recém-chegados no Belo Monte, que doavam a maior parte de seus bens para a comunidade. 
2. Pedro Lima Vasconcellos tem se destacado na análise da presença do texto bíblico na comunidade de Canudos, tendo publicado importantes obras sobre o tema, como Do Belo Monte das promessas à Canudos destruída: o drama bíblico na Jerusalém do sertão (Maceió: Catavento, 2010).

3. A alcunha de Conselheiro, que identifica o líder religioso Antônio Vicente Mendes Maciel, deriva, na verdade, de uma categoria do catolicismo popular nordestino. Segundo Pompa (2015), conselheiros são beatos que "alcançam um estatuto superior", em virtude de sua "habilidade de pregação".

4. Segundo Mello (2014), Dom Luís Antônio dos Santos, Bispo do Ceará, contabiliza, na sua diocese, no ano de 1861, um total de 33 padres para uma população de 720 mil habitantes.

5. Cícero Dantas Martins, o Barão de Jeremoabo, foi um membro da elite agrária baiana do século XIX, com grande inserção na política daquele estado. Proprietário de mais de 60 fazendas, o Barão liderava politicamente a área da Bahia onde estava situado o arraial de Canudos. À época da guerra, contudo, o grupo político do Barão de Jeremoabo encontrava-se fora do Governo baiano, firmando forte oposição a este, a quem responsabilizava pelos fracassos das incursões militares conta o arraial do Conselheiro.

\section{REFERÊNCIAS}

ÂNGELO, Assis. Notícia de cordéis e músicas sobre Canudos. In: FERNANDES, Rinaldo (org.). O Clarim e A oração: cem anos de Os Sertões. São Paulo: Geração, 2002.

ARRUDA, João. Canudos: messianismo e movimento social. 2. ed. Fortaleza: UFC, 2006.

BARTELT, Dawid Danilo. Os custos da modernização: dissociação, homogeneização e resistência no sertão do Nordeste brasileiro. Revista Canudos, v. 3, n. 1, p. 42-60, 1999.

CALASANS, José. Canudos: origem e desenvolvimento de um arraial messiânico. Revista USP, n. 54, p. 72-81, jun./ago. 2002.

CALASANS, José. Coronelismo e Messianismo no Brasil - o caso de Canudos. Revista Unipê, João Pessoa, 1998. Disponível em: $\leq$ http:// josecalasans.com/downloads/artigos/67.pdf >. Acesso em: 25 jun. 2020.

CALASANS, José. O ciclo folclórico do Bom Jesus Conselheiro: contribuição ao estudo da campanha de Canudos. Salvador: Tipografia beneditina, 1950.

CASCUDO, Luís da Câmara. Mouros e Judeus na tradição popular do Brasil. Recife: Governo do Estado do Pernambuco, 1978.

CASTRO, Josué de. Geografia da Fome. 7. ed. Rio de Janeiro: Civilização brasileira, 2007 [1946]. 
CONSELHEIRO, Antônio. Apontamentos dos preceitos da divina lei de nosso senhor jesus cristo para a salvação dos homens. São Paulo: É, 2017 [1897].

CERTEAU, Michel; GIARD, Luce; MAYOL, Pierre. A invenção do cotidiano. 2. ed. Petrópolis: Vozes, 1996.

CUNHA, Euclides da. Os Sertões. São Paulo: Martin Claret, 2016 [1902].

DELLA CAVA, Ralph. Milagre em Joaseiro. 3. ed. São Paulo: Cia das letras, 2014.

DOUGLAS, Mary. Pureza e perigo: ensaio sobre a noção de poluição e tabu. 2. ed. São Paulo: Perspectiva, 2010.

FONTES, Paulo Martins. [Correspondência]. Destinatário: Cícero Dantas Martins (Barão de Jeremoabo). Bahia, 12 dez. 1896. In: SAMPAIO, Consuelo Novais (org.). Canudos: cartas para o barão. 2. ed. São Paulo: Imprensa oficial, 2001.

FONTES, Paulo Martins. [Correspondência]. Destinatário: Cícero Dantas Martins (Barão de Jeremoabo). Bahia, 13 fev. 1899. In: SAMPAIO, Consuelo Novais (org.). Canudos: cartas para o barão. 2. ed. São Paulo: Imprensa oficial, 2001.

GALVÃO, Walnice Nogueira. Euclides da Cunha, precursor. In: PEREIRA, João Baptista Borges; QUEIROZ, Renato da Silva (org.). Messianismo e milenarismo no Brasil. São Paulo: USP, 2015.

GARCEZ, Angelina Nobre Rolim. Aspectos econômicas de Canudos. Salvador: EDUFBA, 1977. Disponível em: <https://repositorio.ufba.br/ ri/handle/ri/27430>. Acesso em: 15 mai. 2021.

GOMES, Flávio dos Santos. Sonhando com a terra, construindo a cidadania. In: PINSKY, Jaime; PINSKY, Carla Bassanezi (org.). História da cidadania. 6. ed. São Paulo: Contexto, 2016.

MARCIANO, João Evangelista de Monte. Relatório apresentado pelo Revd. Frei João Evangelista de Monte Marciano ao Arcebispo da Bahia sobre Antônio Conselheiro e seu séquito no Arraial de Canudos - 1895. Centro de estudos baianos, v. 130. Salvador: UFBA, 1987.

MELLO, Frederico Pernambucano de. A guerra total de Canudos. 3. ed. São Paulo: Escrituras, 2014.

MIRANDA, Marcelino Pereira de. [Correspondência] Destinatário: Cícero Dantas Martins (Barão de Jeremoabo). Tucano-BA, 19 mar. 1897. In: SAMPAIO, Consuelo Novais (org.). Canudos: cartas para o barão. 2. ed. São Paulo: Imprensa oficial, 2001.

POMPA, Cristina. Memória do fim do mundo: o movimento de Pau de colher. In: PEREIRA, João Baptista Borges; QUEIROZ, Renato da Silva (org.). Messianismo e milenarismo no Brasil. São Paulo: USP, 2015.

PONNAU, Dominique. Figuras de Deus: a Bíblia na arte. São Paulo: UNESP, 2006. 
REESINK, Edwin. A maior alegria do mundo: a participação dos índios Kiriri em Belo Monte (Canudos). In: CARVALHO, Maria do Rosário de; CARVALHO, Ana Magda (org.). Índios e caboclos: a história recontada. Salvador: EDUFBA, 2012.

REESINK, Edwin. A Salvação: as interpretações de Canudos à luz das participações indígenas e da perspectiva conselheirista. Raízes: Revista de Ciências Sociais e Econômicas, n. 20, p. 147-158, 12 nov. 1999.

SAMPAIO, Consuelo Novais. Canudos: a construção do medo. In: SAMPAIO, Consuelo Novais (org.). Canudos: cartas para o barão. 2. ed. São Paulo: Imprensa oficial, 2001.

VASCONCELLOS, Pedro Lima. Arqueologia de um monumento: os apontamentos de Antônio Conselheiro. São Paulo: É, 2017.

VASCONCELLOS, Pedro Lima. Do Belo Monte das promessas à Canudos destruída: o drama bíblico na Jerusalém do sertão. Maceió: Catavento, 2010.

SUBMETIDO EM: 15/12/2020

APROVADO EM: 11/05/2021

ก 